\title{
THE MICROBIAL COMMUNITY COMPOSITION OF AN ANAEROBIC REACTOR IN A SUGAR INDUSTRY WASTEWATER TREATMENT PLANT-FROM CLASSICAL TO NEW APPROACHES
}

\author{
Nilgün POYRAZ \\ Department of Biology, Faculty of Science and Humanities, Kütahya Dumlupınar University, Kütahya, TURKEY, \\ e-mail: nilgun.kavak@dpu.edu.tr

\section{Cite this article as:} \\ Poyraz N. 2021. The microbial community composition of an anaerobic reactor in a sugar industry wastewater treatment plant-from classical to new \\ approaches. Trakya Univ J Nat Sci, 22(1): 49-58, DOI: 10.23902/trkjnat.835403
}

Received: 03 December 2020, Accepted: 22 March 2021, Online First: 02 April 2021, Published: 15 April 2021

\section{Edited by:}

Beata Zimowska

\section{ORCID iD of the author:}

orcid.org/0000-0002-5861-7922

Key words:

Anaerobic reactor

$16 S$ rRNA gene cloning

FISH

Microbial diversity

Metagenomic analysis

\begin{abstract}
In this study, the microbial characteristics of the anaerobic reactor of a sugar industry wastewater treatment plant were analyzed using cloning, FISH (Fluoresan in situ hybridization) and metagenomic analysis. Samples were obtained from seven different ports of the reactor on the $148^{\text {th }}$ day of operation. The temperature was maintained at mesophilic conditions. The system's $\mathrm{pH}$ range was operated at 6.8. The cloning results showed that most of the bacterial clones belonged to uncultured members of the Bacteria domain. Many archaeal clones were related to uncultured Archaea and Methanosarcina. The FISH method was applied to determine the microbial composition of the samples, which showed that bacterial and archaeal species had nearly equal rates. Rod-shaped cells, long bacilli, coccus and long chains were detected in the samples.

After metagenomic analysis, in all samples, Archaea domain members ranged between 60 $36 \%$ and Bacteria domain members ranged between $58-31 \%$. At the phylum level, in all samples, Euryarchaeota was the most dominant phylum. Proteobacteria (14.8-21.97\%) and Actinobacteria (5.53-15.94\%) phyla were high in rate. Furthermore, members of Spirochaeotes (0.63-4.82\%) and Bacteroidetes (1.72-2.38\%) were analyzed in the samples. This study revealed both bacterial and archaeal populations in the reactor of highconcentration organic sugar wastewater. These results will help in the development of more efficient anaerobic treatment systems.
\end{abstract}

Özet: Çalışmada bir şeker endüstrisi atık su arıtma tesisinin anaerobik reaktörünün mikrobiyal özellikleri klonlama, FISH (Floresan in situ hibridizasyon) ve metagenomik analiz kullanılarak analiz edilmiştir. Örnekler 148. operasyon gününde reaktörün yedi farklı girişinden alınmıştır. Sıcaklık mezofilik koşullarda tutulmuştur. Sistem $6,8 \mathrm{pH}$ aralığında çalışmıştır. Klonlama sonuçları, bakteri klonlarının çoğunun kültüre alınmamış Bacteria üyelerine ait olduğunu göstermiştir. Birçok arkeal klon, kültüre alınmamş Archaea ve Methanosarcina ile ilişkilidir. FISH yöntemi de örneklerin mikrobiyal kompozisyonunu belirlemek için uygulanmıştır. Elde edilen sonuçlar bakteriyel ve arkel türlerin neredeyse eşit oranlarda bulunduğunu göstermiştir. Örneklerde çubuk şeklindeki hücreler, uzun basiller, koklar ve uzun zincirler tespit edilmiştir.

Metagenomik analiz sonuçları değerlendirildiğinde ise, tüm örneklerde, Archaea domaini üyelerinin \%60-36 oranları arasında ve Bakteri domaini üyelerinin ise \%58-31 oranları arasında bulunduğu belirlenmiştir. Filum düzeyinde, tüm örneklerde Euryarchaeota filumunun en baskın filum olduğu saptanmıştır. Proteobacteria $(\% 14,8-21,97)$ ve Actinobacteria $(\% 5,53-15,94)$ filumlarının da yüksek oranda olduğu görülmüştür. Ayrıca örneklerde Spirochaeotes $(\% 0,63-4,82)$ ve Bacteroidetes $(\% 1,72-2,38)$ üyeleri analiz edilmiştir. Bu çalışma, yapılan analizler ile yüksek konsantrasyonlu organik şeker atıksu reaktöründe hem bakteriyel hem de arkael popülasyonları ortaya çıkarmıştır. Bu sonuçlar, daha verimli anaerobik arıtma sistemlerinin geliştirilmesine yardımcı olacaktır.

\section{Introduction}

The first modern wastewater plant in the world was built in Hamburg in 1842, and 12 years later, in 1855, the first sewer was built in Chicago. The treatment plant was constructed after 1870 . In the middle of the $20^{\text {th }}$ century, regulations came into force, and the Federal Water
Pollution and Control Law was created in America in 1948 (Y1ldiz et al. 2013). The increasing amount of wastewater accelerated the development of more serious discharge arrangements and alternative methods for biological wastewater treatment. The increase in research 
on biofilm systems in the 1980s led to the development of innovative and flexible processes.

Waterborne disease outbreaks, eutrophication and micro-pollutants, combined with underdeveloped infrastructure and poor economy make the issues associated with the disposal and treatment of wastewater even more serious. Therefore, research should be conducted to develop efficient, low-cost and lowmaintenance systems (Andersson 2009).

Anaerobic treatment technology refers to the biological treatment of organic wastes and wastewater without oxygen, and with the use of this technology, operating costs are reduced and biogas (methane) is produced from organic wastes as an alternative energy source (Narihiro \& Sekiguchi 2007). The greatest application of this technology is as a sludge digester, which is widely used in municipal wastewater treatment plants. Conversion of organic substances to biogas anaerobically is a complex multi-stage process involving interactions between many different types of bacteria and archaea. Microbial processes, each performed by a certain group of microorganisms, can be defined as hydrolysis, acidogenesis, acetiogenesis and methanogenesis (Venkiteshwaran et al. 2015).

However, it is important to ensure and maintain a balanced reaction rate between steps or groups to ensure a fast and stable treatment. Microbial diversity and activity information is also important for proper application and selection of a vaccine mud. The microbial community structure in the anaerobic digester is affected by many environmental parameters (Chen et al. 2008). Due to these reasons, one of the most advanced technological areas in recent years is the microbiology of anaerobic treatment processes. In order to better control the biological processes, detailed information about the ecology and function of microbial communities in these processes is required. Detailed structures of community compositions can be revealed through cultureindependent analyses that target the $16 \mathrm{~S}$ rRNA gene.

In the present study, sugar industry wastewater containing high concentrations of hydrocarbon and sugar was used. In addition to traditional methods such as FISH (Fluoresan in situ hybridization) and cloning, 16S rRNA gene-targeted metagenomic studies were applied to determine the microbial diversity of the facility and carry out an analysis of wastewater microbial diversity based on modern methods.

\section{Materials and Methods}

\section{Sampling}

Since the beet sugar factory treatment plant is an anaerobic feature, anaerobic sludge samples were obtained from 7 different ports of an upstream anaerobic sludge blanket reactor (UASB) on the $148^{\text {th }}$ day of operation from facility in Eskisehir. Samples were collected in $5 \mathrm{~L}$ sterile bottles and transferred to the laboratory within 1 hour.
Determination of the physical and chemical parameters of the samples

Temperature, $\mathrm{pH}$ and element concentrations of the samples were measured. Some element contents of water samples were determined by the ICP-OES device (Perkin Elmer) within the Anadolu University Plant Medicine and Scientific Research Center (BİBAM). The optical emission spectrometry was determined with Optima 4300 DV device, and the $\mathrm{pH}$ was measured with a $\mathrm{pH}$ meter (Mettler Toledo).

\section{Total DNA extraction from samples}

DNA extraction was performed for all samples of the reactor. For efficient and high-quality DNA extraction, the protocol proposed by Singka et al. (2012) was used with small modifications. In addition to the lysis step with glass beads, lysozyme $(3 \mathrm{mg} / \mathrm{ml})$ was added and incubated at $37^{\circ} \mathrm{C}$ for 15 minutes in a shaking incubator at $150 \mathrm{rpm}$. Then, proteinase $\mathrm{K}(150 \mathrm{mg} / \mathrm{ml})$ and $10 \%$ sodium dodecyl sulfate (SDS) were added and incubated at $37^{\circ} \mathrm{C}$ for 40 minutes in the shaking incubator. After extraction, the DNA was checked by gel electrophoresis and Nanodrop (between 1.8-2.0 in 260-280 nm, more than 1.7 in 260-230 nm).

\section{Amplification by PCR for $16 S$ rRNA gene}

PCR reaction was established using archaea- and bacteria-specific primers from Total DNA. To establish a PCR reaction, bacteria-specific 27F (5'AGAGTTTGATCATGGCTCAG-3') and 21F (5'TCCGGTTGATCCYGCCGG-3') were used for Archaea as the forward primer and 1492R (5'GGTTACCTTGTTACGACTT3') (Lane et al. 1985) was used for both Archaea and Bacteria. Bacter 50 program was used for 16S rRNA amplification of bacteria and Archaea members. The reaction conditions of the Bacter 50 program were a cycle of $94^{\circ} \mathrm{C}$ for $3 \mathrm{~min}, 30$ cycles of $94^{\circ} \mathrm{C}$ for $15 \mathrm{~s}$, $55^{\circ} \mathrm{C}$ for $30 \mathrm{~s}$, and $72^{\circ} \mathrm{C}$ for $2 \mathrm{~min}$, as well as an extension step of $7 \mathrm{~min}$ at $72^{\circ} \mathrm{C}$. Applied Biosystems ${ }^{\circledR}$ Thermal Cycler was used for the reactions. In all studies, both positive and negative control reactions were prepared. The obtained PCR products were controlled by applying $5 \mathrm{~V} / \mathrm{cm}$ current in $1 \mathrm{X}$ TAE (Tris-Acetic acid-EDTA) buffer to $1 \%$ agarose gel (Mutlu \& Güven, 2015).

\section{$\underline{16 S \text { rRNA cloning }}$}

The ligation of the $16 \mathrm{~S}$ rRNA gene region to the vector system was performed using the T4 DNA Ligase enzyme according to the conditions specified in the TA cloning kit (Invitrogen) protocol. After all the components were added, it was incubated overnight at $14^{\circ} \mathrm{C}$. The samples obtained after ligation were placed on ice, and a $50 \mu \mathrm{l}$ vial containing the competent cells was opened on ice and $2 \mu 1$ of the ligation reaction was added to them. The vials were incubated on ice for 30 minutes and then kept at $42^{\circ} \mathrm{C}$ for 30 seconds. The cells were quickly transferred to ice. Then, $250 \mu \mathrm{l}$ of SOC medium was added to the samples and incubated at $37^{\circ} \mathrm{C}$ for 60 minutes at $225 \mathrm{rpm}$ in a shaking incubator. 10-200 $\mu \mathrm{l}$ was taken from each prepared transformation vial and cultivated in LB Agar Petri plates containing $100 \mu \mathrm{g} / \mathrm{ml}$ ampicillin and X-gal and kept in the 
incubator at $37^{\circ} \mathrm{C}$ overnight. Then, white colonies were selected from the Petri dishes. The white colonies and blue colonies were selected according to the X-gal degradation and fragmentation. The glycerol stock was prepared to be stored at $-80^{\circ} \mathrm{C}$ from the selected white colonies.

Plasmid isolation was performed using the plasmid isolation kit from the obtained white colonies. If the insert was on vector, positive clones were screened for by amplified rDNA restriction analysis (ARDRA) (Vaneechoutte et al. 1992) with the enzymes HinfI and MboI (New England Biolabs) for different patterns. Clones with different restriction patterns were selected for sequencing and sent to sequence analysis using M13 forward and reverse primers. The chromatogram results from the sequence analysis were displayed with the programs BioEdit and Chromas Lite, and the sequences were compared with data in NCBI BLAST and 16S rRNA databases to match the species with the highest similarity. The accession numbers were obtained from NCBI for $16 \mathrm{~S}$ rRNA sequence regions for all the clones obtained, and their records were provided to the gene bank.

Phylogenetic trees were constructed using the MEGA $\mathrm{X}$ program (Kumar et al. 2018) and the NearestNeighbor-Interchange (NNI) method (Saitou \& Nei 1987). The bootstrap method (1000 replicates) was used for evaluation of the validity of the tree topology. The Jukes-Cantor algorithm was chosen for calculation of the distance matrix (Jukes \& Canthor 1969).

\section{Microbial community analysis with FISH method}

The FISH technique was applied to determine the microbial composition of the samples. For this purpose, the protocols of Amann et al. (1995) and Daims et al. (2005) were modified and used. First, the fixation process was applied to the wastewater samples. The fixed samples were homogenized and then vortexed. Samples of different volumes were taken, and $10 \mathrm{ml}$ of 1X PBS was added, after which the mixture was passed through a $0.2 \mu \mathrm{m}$ pore diameter GTTP Isopore (Millipore) filter. To wash the filter, it was passed through a 1X $10 \mathrm{ml}$ PBS filter again (Aman et al. 1995). An in situ hybridization buffer was prepared for the hybridization of the fixed and filtered samples. A mixture of $18 \mu 1$ in situ hybridization buffer for reaction and $2 \mu \mathrm{l}$ probe at $50 \mathrm{ng} / \mu \mathrm{l}$ concentration from ARC344 for Archaea and EUB338 for Bacteria were mixed. In addition, specific probes (Methanomicrobiales inclusive for Methanosarcinaceae specific MG1200) (CGGATAATTCGGGGCATGCTG) were used for specific groups (Raskin et al. 1994) The samples were horizontally placed in a hybridization oven (Biometra OV3) for hybridization and incubated for 3 hours at $46^{\circ} \mathrm{C}$. They were washed to remove unbound probes after hybridization (Aman et al. 1995). After the filters were dried, they were stained with DAPI (4',6'diamidino-2-phenylindole-dihydrochloride) and examined under an epifluorescent microscope (Leica DM6000B) at 100X lens (Daims et al. 2005).

\section{Metagenomic analysis}

For this purpose, total genomic DNA extraction was performed on the samples to be analyzed, and DNA concentration was measured in NanoDrop in order to determine the DNA quality. After total nucleic acid extraction, DNA amplification, amplicon library construction, and next-generation sequencing studies were performed for highly efficient gene sequencing based on $16 \mathrm{~S}$ rDNA from extracts. GATC Biotech provided support for these analyses. For genomic DNA amplification, a barcode primer set according to the protocols was used, adapted to the Illumina device. The NCBI database was used for taxonomic profiling and KEGG functional profiling of microbial communities was used for the integrated gene catalogue of the human gut microbiome (IGC). Estimation of diversity indices and community composition were performed QIIME (Quantitative Insights into Microbial Ecology) and R software (Caporaso et al. 2010, Oksanen 2013).

\section{Results}

\section{Physicochemical parameters of samples}

The sample collection was carried out from the bottom port $(1 \mathrm{M}-2 \mathrm{M} \ldots)$ to the upper port $(7 \mathrm{H} 2)$ of the reactor. Samples were taken on the $148^{\text {th }}$ operation day of the reactor. The system's temperature was adjusted to mesophilic value of $34.0 \pm 1^{\circ} \mathrm{C}$ controlling the temperature panel. The overall system's average $\mathrm{pH}$ range was at 6.8. The $\mathrm{pH}$ values of samples from the lower part to the upper part were measured as $6.88,6.89,7.16,7.11$, 7.84, 7.20 and 6.92, respectively. $\mathrm{Mg}^{+2}$ and $\mathrm{Ca}^{+2}$ concentrations were high. The $\mathrm{Mg}^{+2}$ contents of samples from the lower part to the upper part were determined as 341.1, 302.9, 272.1, 292.3, 337.7, 287.3, 324.2, 348.1 and $341.4 \mathrm{ppm}$, respectively. The $\mathrm{Ca}^{+2}$ contents of samples from the lower part to the upper part were determined as 309.8, 179.21, 186.6, 159.08, 315.0, 207.5, 425.9, 320.4 and $113.0 \mathrm{ppm}$, respectively. The obtained samples were stored at $-20^{\circ} \mathrm{C}$ within 60 minutes and samples were kept frozen until DNA extraction.

\section{S rRNA cloning}

Using ARDRA, 189 Archaea clones and 282 Bacteria clones were analyzed, which yielded 12 different patterns for Archaea and 25 different patterns for Bacteria. At least 76 clones from the restriction pattern were chosen for sequencing.

Environmental 16S rRNA gene sequences from the samples were stored in the GenBank with these accession numbers MT322876-MT322913, MT325975-MT325986 and MT325989-MT326014. Most of the bacterial clones were related to uncultured Bacteria. Many archaeal clones were related to uncultured Archaea and Methanosarcina. For phylogenetic analysis, the maximum-likelihood treeing algorithm in the MEGA $X$ program was used. The phylogenetic trees for Bacteria and Arhaea, constructed based on partial $16 \mathrm{~S}$ rRNA sequences, were shown in Fig. 1 and 2 . 


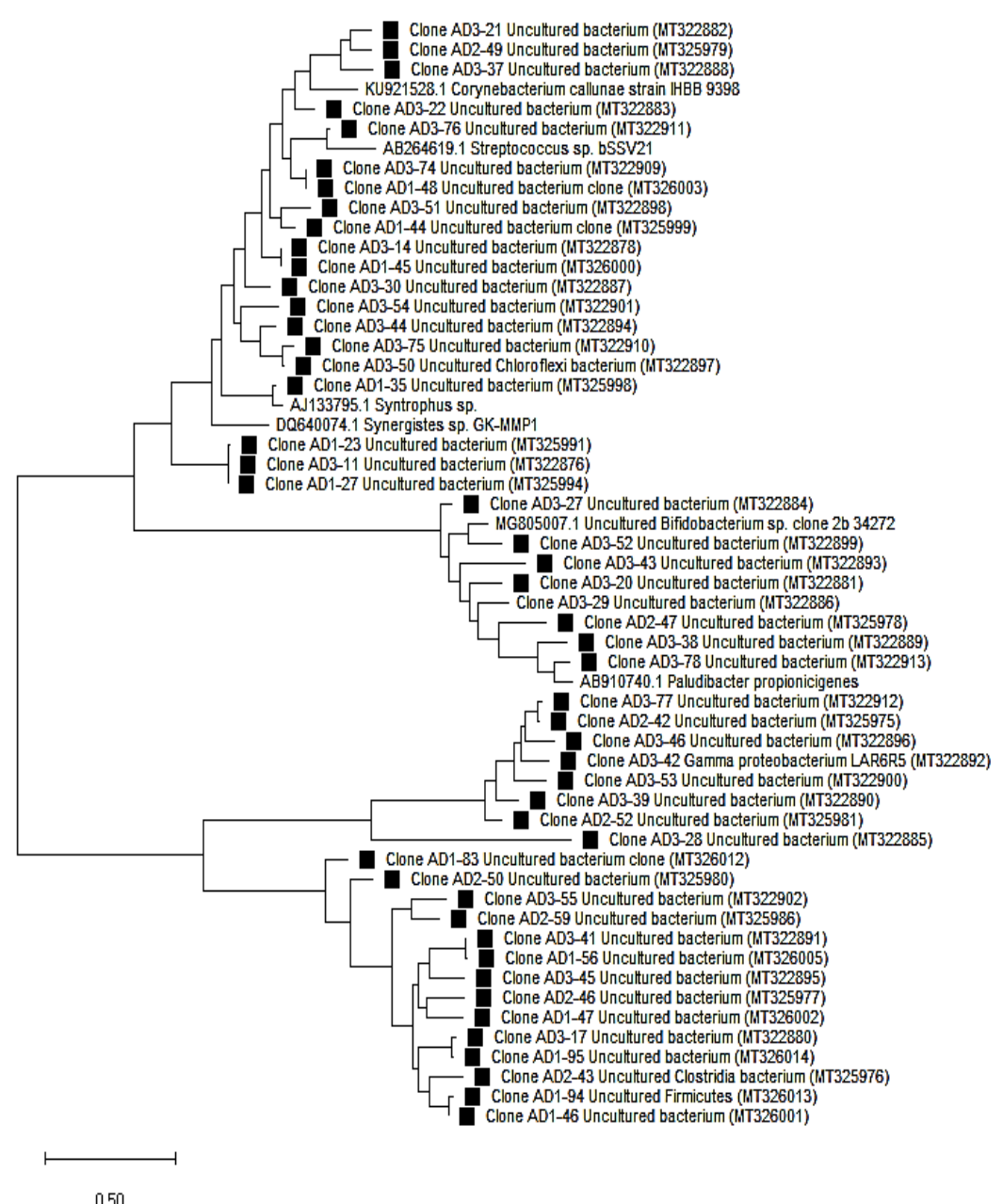

Fig. 1. Phylogenetic tree based on 16S rRNA gene sequences from clones belonging to Bacteria (indicated by squares). The scale bar represents the expected number of substitutions per site. Bootstrap support values below $50 \%$ were not included in the figure.

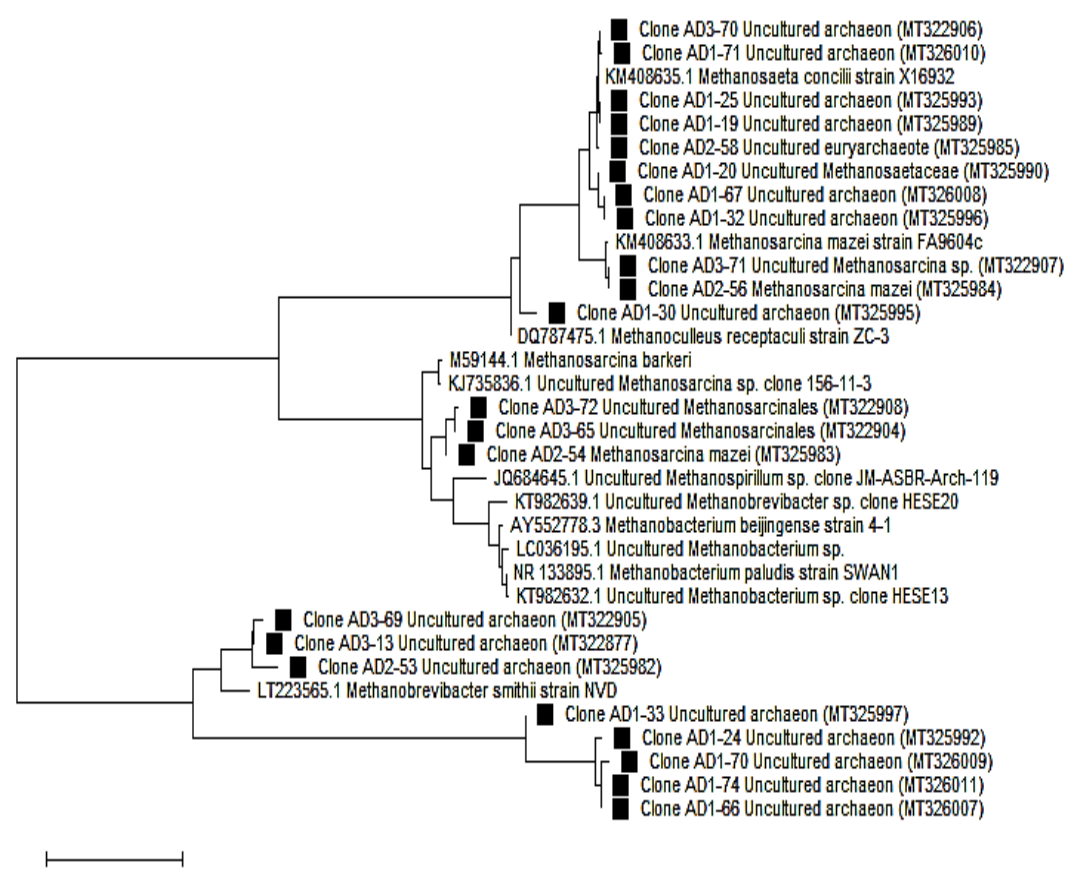

0.50

Fig. 2. Phylogenetic tree based on $16 \mathrm{~S}$ rRNA gene sequences from clones belonging to Archaea (indicated by squares). The scale bar represents the expected number of substitutions per site. Bootstrap support values below $50 \%$ were not included in the figure. 

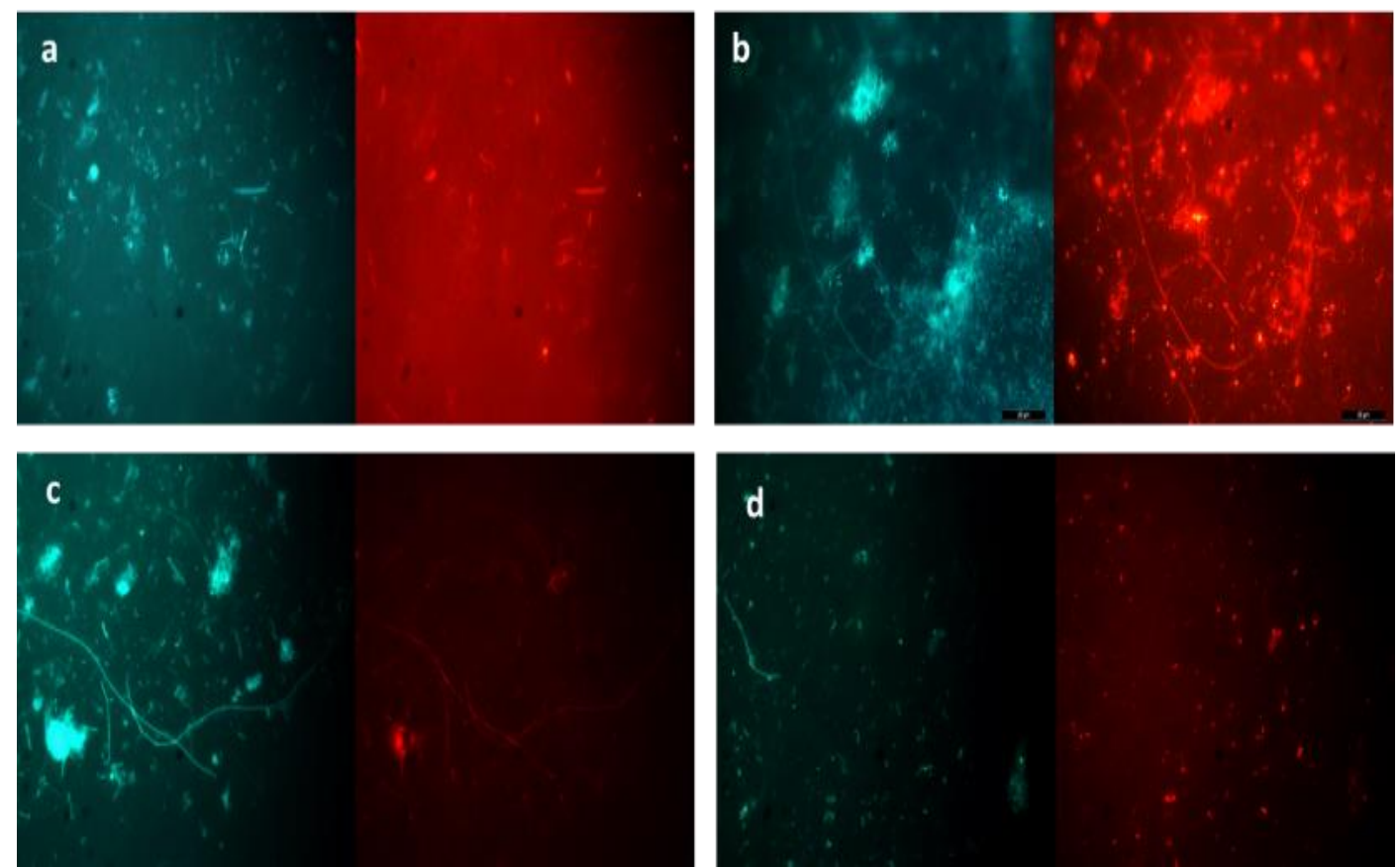

Fig. 3. Images of the samples' microbiota (a-d). DAPI staining is shown on the left, and hybridization signals with FISH probes Arc344 (a, b), MG1200 (c) and Eub338 (d) on the right. Image sources were 3M (a), 2M (b) and 5M samples (c, d).

\section{FISH results}

The FISH analysis of the samples showed that bacterial and archaeal species had nearly equal rates. Rodshaped cells, long bacilli, coccus and long chains were detected in the samples (Fig. 3).

Positive signals were received as a result of hybridizations with ARC 344, EUB338, and MG1200 probes. Total cell number calculations concluded that microbial cells in the samples was very high; total cells were nearly $10^{10}-10^{11}$ cells $\mathrm{mL}$. The concentrations of bacteria for the seven samples ranged between $2.68 \times 10^{10} \pm 4.29 \times 10^{9}$ and $5.07 \times 10^{10} \pm 7.20 \times 10^{9}$ cells per $\mathrm{mL}$ of samples (Table 1). When compared with the total cell counts determined by DAPI staining, the ratio of bacteria varied between roughly $48 \%$ and $60 \%$ of the total cell numbers. Archaeal cells ranged between $2.45 \times 10^{10} \pm 4.02 \times 10^{9}$ and $3.99 \times 10^{10} \pm 1.05 \times 10^{10}$ cells per $\mathrm{ml}$ of samples. The percentage of archaea ranged between $38 \%$ and $52 \%$ of the total cell numbers. The concentrations of Methanomicrobiales, inclusive of Methanosarcinaceae cells, were between $1.78 \times 10^{10} \pm 4.44 \times 10^{9}$ and $2.91 \times 10^{10} \pm 3.60 \times 10^{9}$. This archaeal group was dominant, containing $22-37 \%$ of the total archaeal population. The high percentages of standard deviations in the results may be due to high background fluorescence in the samples, affecting the correct probe signal acquisition.

Table 1. Cell counts with DAPI, \% Archaea, and Bacteria with FISH probes.

\begin{tabular}{|c|c|c|c|c|}
\hline SAMPLE & $\begin{array}{l}\text { DAPI counts/ml } \\
(\text { mean SD })\end{array}$ & $\begin{array}{l}\text { EUB338 counts/ml } \\
(\text { mean SD) }(\%)\end{array}$ & $\begin{array}{l}\text { ARC } 344 \text { counts/ml } \\
\quad(\text { mean SD) }(\%)\end{array}$ & $\begin{array}{l}\text { MG1200 counts/ml } \\
(\text { mean } \mathrm{SD})(\%)\end{array}$ \\
\hline $1 \mathrm{M}$ & $6.64 \times 10^{10} \pm 8.32 \times 10^{9}$ & $\begin{array}{c}3.24 \times 10^{10} \pm 2.12 \times 10^{9} \\
(48 \%)\end{array}$ & $\begin{array}{c}3.53 \times 10^{10} \pm 4.78 \times 10^{9} \\
(52 \%)\end{array}$ & $\begin{array}{c}2.22 \times 10^{10} \pm 8.50 \times 10^{8} \\
(33 \%)\end{array}$ \\
\hline $2 \mathrm{M}$ & $7.97 \times 10^{10} \pm 4.82 \times 10^{9}$ & $\begin{array}{c}4.57 \times 10^{10} \pm 6.52 \times 10^{9} \\
(53 \%)\end{array}$ & $\begin{array}{c}3.99 \times 10^{10} \pm 1.05 \times 10^{10} \\
(47 \%)\end{array}$ & $\begin{array}{c}2.91 \times 10^{10} \pm 3.60 \times 10^{9} \\
(34 \%)\end{array}$ \\
\hline $3 \mathrm{M}$ & $1.03 \times 10^{11} \pm 2.57 \times 10^{10}$ & $\begin{array}{c}3.52 \times 10^{10} \pm 2.71 \times 10^{9} \\
(51 \%)\end{array}$ & $\begin{array}{c}3.36 \times 10^{10} \pm 5.29 \times 10^{8} \\
(49 \%)\end{array}$ & $\begin{array}{c}2.13 \times 10^{10} \pm 5.77 \times 10^{8} \\
(31 \%)\end{array}$ \\
\hline $4 \mathrm{M}$ & $9.89 \times 10^{10} \pm 2.35 \times 10^{10}$ & $\begin{array}{c}5.07 \times 10^{10} \pm 7.20 \times 10^{9} \\
(60 \%)\end{array}$ & $\begin{array}{c}3.36 \times 10^{10} \pm 3.07 \times 10^{9} \\
(40 \%)\end{array}$ & $\begin{array}{c}1.87 \times 10^{10} \pm 5.35 \times 10^{9} \\
(22 \%)\end{array}$ \\
\hline $5 \mathrm{M}$ & $6.57 \times 10^{10} \pm 1.53 \times 10^{9}$ & $\begin{array}{c}2.68 \times 10^{10} \pm 4.29 \times 10^{9} \\
(52 \%)\end{array}$ & $\begin{array}{c}2.45 \times 10^{10} \pm 4.02 \times 10^{9} \\
(48 \%)\end{array}$ & $\begin{array}{c}1.88 \times 10^{10} \pm 4.90 \times 10^{9} \\
(37 \%)\end{array}$ \\
\hline $6 \mathrm{M}$ & $6.99 \times 10^{10} \pm 1.47 \times 10^{10}$ & $\begin{array}{c}4.69 \times 10^{10} \pm 3.48 \times 10^{9} \\
(62 \%)\end{array}$ & $\begin{array}{c}2.85 \times 10^{10} \pm 1.07 \times 10^{10} \\
(38 \%)\end{array}$ & $\begin{array}{c}1.83 \times 10^{10} \pm 1.91 \times 10^{9} \\
(24 \%)\end{array}$ \\
\hline $7 \mathrm{H} 2$ & $7.09 \times 10^{10} \pm 1.35 \times 10^{10}$ & $\begin{array}{c}3.73 \times 10^{10} \pm 4.58 \times 10^{8} \\
(60 \%)\end{array}$ & $\begin{array}{c}2.48 \times 10^{10} \pm 1.55 \times 10^{9} \\
(40 \%)\end{array}$ & $\begin{array}{c}1.78 \times 10^{10} \pm 4.44 \times 10^{9} \\
(29 \%)\end{array}$ \\
\hline
\end{tabular}




\section{Metagenomic analysis}

After analyzing the samples, microbial diversity and loading showed some differences. In all samples, Archaea members ranged between 60-36\%, and Bacteria members ranged between $58-31 \%$. At the phylum level, in all samples, Euryarchaeota was the most dominant phylum; $1 \mathrm{M}, 2 \mathrm{M}, 4 \mathrm{M}$, and $7 \mathrm{H} 2$ had more than $50 \%$ of it. Proteobacteria (between 14.8-21.97\%) and Actinobacteria (between 5.53-15.94\%) phyla had a high rate. Members of Spirochaeotes (between 0.63-4.82\%) and Bacteroidetes (between 1.72-2.38\%) were also analyzed in the samples. At the genus level, there were some differences. Methanosaeta was the most dominant genus in sample 1M (55.75\%) and sample 7H2 (60.48\%), while Methanosarcina was the most dominant genus in other samples. Nearly half of the community structures of 3M, 4M, and 6M consisted of Methanosarcina members. Members of Corynebacterium, Serratia, Streptococcus, Bifidobacterium, Spharochaeta, Clostridium, Acinetobacter, and Pseudomonas were detected in the samples. At the species level, Methanosaeta concilii was dominant in the samples (Fig. 4). Corynebacterium callunae was also dominant. The frequency was nearly the same in samples $2 \mathrm{M}, 3 \mathrm{M}, 4 \mathrm{M}, 5 \mathrm{M}$, and $6 \mathrm{M}$. The other species found were Methanosarcina vacuolata, Serratia marcescens, Methanosarcina sp., and Methanosarcina barkeri. In sample 7H2, Streptococcus agalacticae and Serratia marcescens were detected. Members of Clostridium saccharoperbutylacetonicum were observed in samples 5M and 6M (Fig. 4).

The diversity index is a quantitative measure that shows many different species in a dataset as well as the distribution of these species. It increases when the number of species increases and when all species are present at nearly the same level. The diversity indices were calculated using the vegan package in $\mathrm{R}$ and QIIME softwares (Table 2).

\section{Global gene functional profiles}

To detect of the functional profiling of the anaerobic sludge samples, the total reads were consolidated based on the categories of the KEGG database. KEGG analysis showed that $9.70-10.91 \%$ of the total reads were related to genetic information processing, 5.20-6.57\% were assigned to replication and repair, $3.99-6.41 \%$ were related to carbohydrate metabolism, and $4.69-5.11 \%$ corresponded to cellular processes and signaling in anaerobic digestion sludge (Fig. 5).

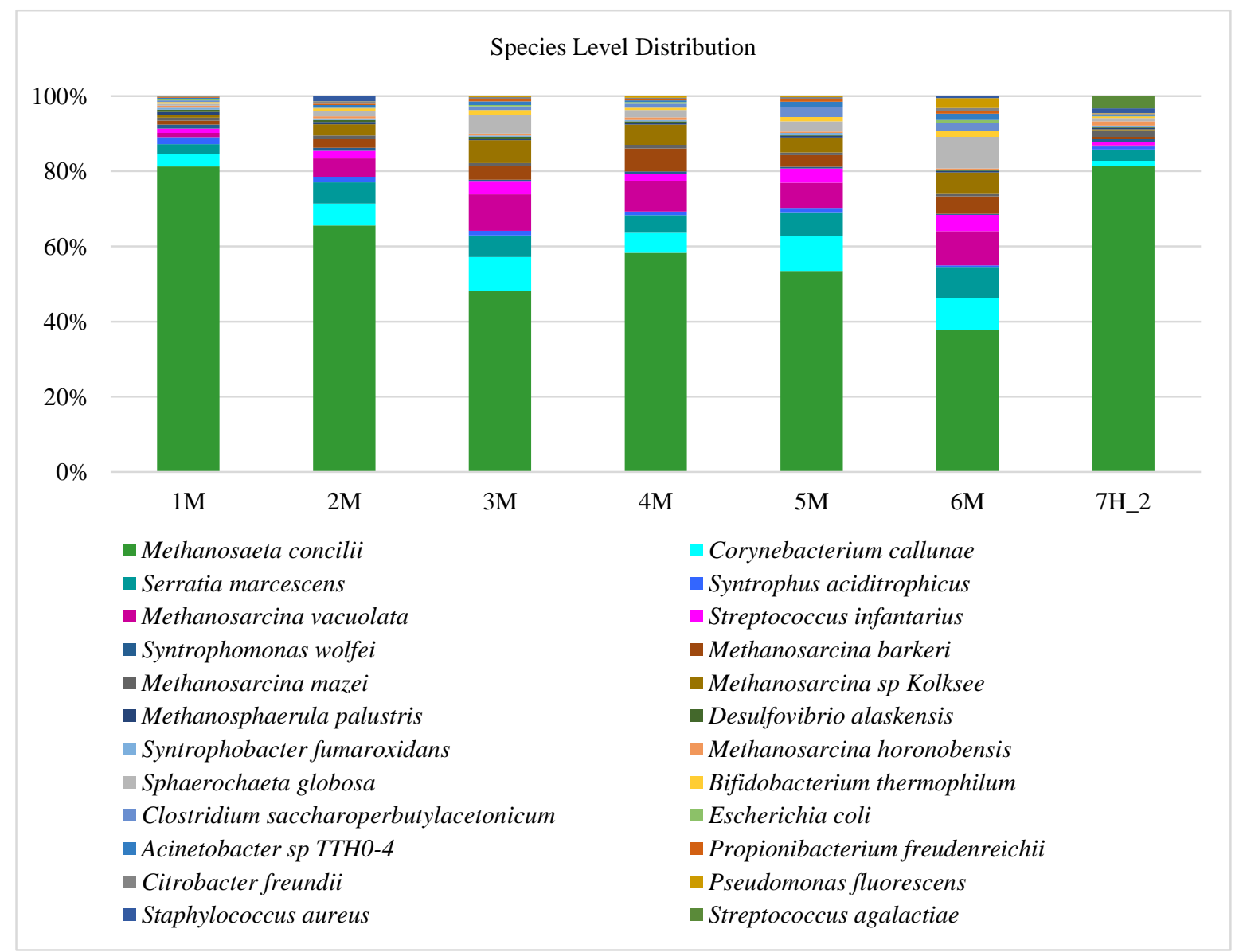

Fig. 4. Species level distribution of samples. 
Table 2. Diversity indices of the microbial communities of the samples

\begin{tabular}{|c|c|c|c|c|c|c|}
\hline Sample & $\begin{array}{l}\text { Simpson } \\
\end{array}$ & $\begin{array}{l}\text { Shannon } \\
\end{array}$ & InvSimpson & "Alpha & "SpeciesNo & Evenness \\
\hline $1 M$ & 0.660822175 & 3.228583887 & 2.94830595 & 247.0938675 & 1826 & 0.429911 \\
\hline $2 \mathrm{M}$ & 0.784162313 & 3.723042476 & 4.633111177 & 247.7199183 & 1830 & 0.495608 \\
\hline $3 \mathbf{M}$ & 0.88338962 & 4.170978223 & 8.575565914 & 247.7199183 & 1830 & 0.555237 \\
\hline $4 M$ & 0.825997654 & 3.846167703 & 5.747048941 & 247.5633824 & 1829 & 0.512036 \\
\hline $5 M$ & 0.861639717 & 4.076570752 & 7.227507625 & 247.5633824 & 1829 & 0.542709 \\
\hline $6 \mathrm{M}$ & 0.921908257 & 4.361425656 & 12.80545119 & 247.5633824 & 1829 & 0.580631 \\
\hline $7 \mathrm{H2}$ & 0.596514623 & 2.76219843 & 2.478404567 & 246.9373935 & 1825 & 0.367835 \\
\hline
\end{tabular}

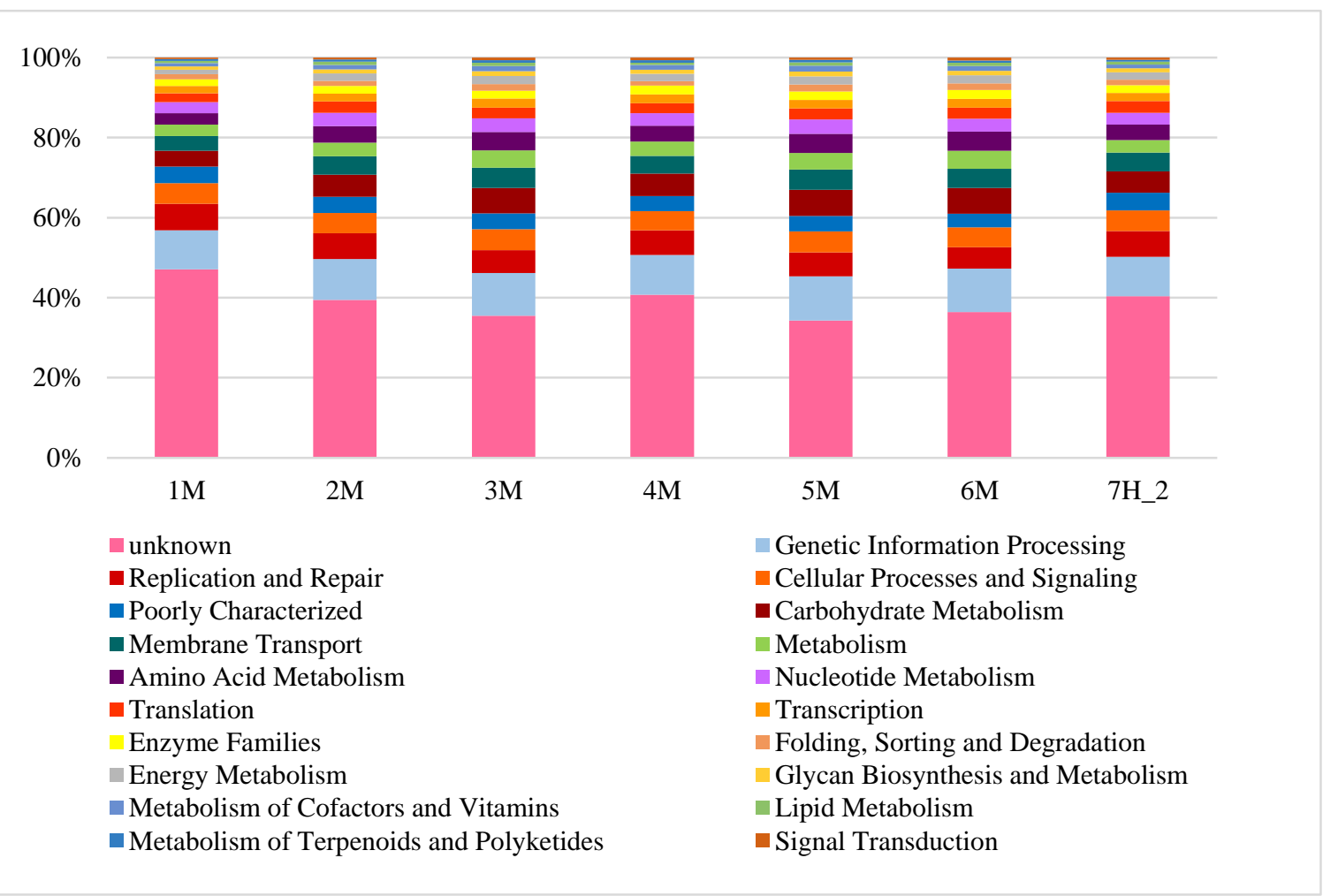

Fig. 5. Functional gene categories of the samples.

\section{Discussion}

Anaerobic digestion contains highly complex microbial communities that convert substrates into methane-containing biogas for renewable energy. These microbial communities play critical roles in excess sludge treatment, particularly in determining sludge reduction performance and methane production efficiency. Anaerobic digestion process is accomplished through a series of processes based on the interaction of bacteria and archaea, and it is important to minimize changes in microorganism dynamics and distribution during methane production and to monitor changes to maintain stable performance (Nakasaki et al. 2015). Therefore, the relationship between the microbial community structure and function needs to be understood well.

For the analysis of a wide variety of environmental samples such as water and wastewater systems and anaerobic systems, traditional methods such as ARDRA (16S-RFLP), t-RFLP, DGGE, gene cloning based on the comparison and amplification of rRNA sequences gene and FISH have been applied.
Analysis techniques based on nucleic acid have been developed to explain the structure of the community without developing microorganisms in the culture medium (Gilbride et al. 2006, Nayak et al. 2009, Vanwonterghem et al. 2014).

In this study, we applied both traditional methods (FISH and cloning) and metagenomic approaches. The cloning results showed that most of the bacterial clones were related to uncultured members of the Bacteria domain. Many archaeal clones were related to uncultured Archaea and Methanosarcina. Cloning and sequencing of the 16S rRNA gene has often been applied to explain the full structure of a microbial community. However, there are microbial clones that are very difficult to classify phylogenetically, and most of the clones are closely related to uncultured strains. There may be some errors in detecting the microorganism community by gene cloning. Since different cells have different 16S rRNA gene copies, inappropriate primer clusters can cause problems in differentiating some microbial species. Thus, many methods have been used in our study to reduce errors. Moreover, clone library sequencing of the $16 \mathrm{~S}$ rRNA 
gene for microbial ecology studies may lead to overestimation or underestimation of the number and diversity of microorganisms due to deviations in amplification (Ye et al. 2012, Aird et al. 2011, Gao et al. 2012).

FISH was also applied, but in wastewater samples, there are humic acids, metals, colloids, and organic and inorganic substances, all which can affect the penetration of the probes into the cells. Thus, samples need pretreatment steps. These steps may change the results of bacterial and archaeal numbers. We found that bacterial and archaeal species were of nearly equal rates in the samples. In a similar study, Khan et al. (2019) detected specific groups of bacteria in the anaerobic digester sludge samples. The number of cells hybridized by the probe EUBmix ranged between 54-89\%, and there were different morphologies like cocci, rods, and filaments.

Metagenomic approaches include the analysis of all the genomes of the members of a microbial community. Cloning and genome analysis are conducted without cultivating the organisms in the community. This provides an additional tool for studying non-cultured species. Therefore, the new generation of high-throughput sequencing provides a powerful tool to study the microbial community structure (Albertsen et al. 2013, Bragg \& Tyson 2014). Thus, in our study, microbial communities in an anaerobic reactor were analyzed using both traditional and modern methods to show the species structure and relations between microorganisms. The use of NGS facilitated detailed analyses of both archeal and bacterial community structures.

When previous studies were evaluated, more than 20 methanogenic bacterial phyla were detected in anaerobic waste and wastewater sludges. The 16S rRNA gene clones' sequencing results concluded various prokaryotic taxa such as Proteobacteria (especially Deltaproteobacteria class), Chloroflexi, Firmicutes, Spirochaetes, and Bacteroidetes. Similarly, clones in the Archaea domain in the classes Methanomicrobia, Methanobacteria, and Thermoplasmata were typical of the clones found in such muds (Narihiro \& Sekiguchi 2007). Microbial diversity in full-scale biogas production reactors has been reported using metagenomic studies. In most studies, the results were similar. Guo et al. (2015) determined that in anaerobic sludge, Bacteria members were dominant (93\%), while Archaea members made up $5.6 \%$ of it. It was determined that the most abundant bacterial populations were members of Proteobacteria, Firmicutes, Bacteroidetes, and Actinobacteria at phylum level. The largest class in the Euryarchaeota phylum is Methanomicrobia. It was stated that the predominance of Methanomicrobia was associated with the discovery of Methanosaeta and Methanosarcina. When our results were compared with this study for functional analysis, it was concluded that a large number of the reads belonged to metabolism. In the category of metabolism, energy production and conversion, amino acid transport and metabolism, and carbohydrate transport and metabolism were dominant. In our study, the total reads were related to genetic information processing, replication, and repair. $3.99-6.41 \%$ of the reads were related to carbohydrate metabolism. These results can be used for detecting pathways for the conversion of activated sludge into methane (Guo et al. 2015).

In another study, the microbial structure of cassava alcohol wastewater plant was analyzed with the clone libraries by using 16S rRNA gene. Most bacterial OTUs were identified as phyla of Firmicutes, Chloroflexi, Proteobacteria and Bacteroidetes. Methanosaeta, Methanobacterium, Methanomethylovorans and Methanosarcina were the most abundant archaeal groups (Gao et al. 2012). However, in our study, Bacteria and Archaea members had nearly equal rates. To summarize, 30315, 32316, 35562, 21255, 28716, 19821 and 27812 sequences were analyzed, respectively, and the microbial community structure was revealed at species and genus levels. The Shannon, Simpson, and Evenness indices changed between 2.76-4.36, 0.59-0.92 and 0.36-0.58, respectively. The calculation of these diversity indices yielded higher diversity values. Between $36-60 \%$ of the identified sequences belonged to Archaea, while 31-58\% belonged to Bacteria. Euryarchaeota was the most dominant phylum, with nearly $50 \%$ rate of the total sequences. The dominant orders were acetotrophic Methanosaeta and Methanosarcina. In Bacteria, the dominant genera were Corynebacterium, Serratia, Streptococcus, Bifidobacterium, Sphaerochaeta, Clostridium, Acinetobacter and Pseudomonas. The most dominant species detected were Methanosaeta concilii and Methanosarcinia vacuolata in Archaea and Corynebacterium callunae in Bacteria. In the study conducted by Ambuchi et al. (2016), 31 phyla were detected, similar to our study. The predominant microbial community phyla belonged to Chloroflexi (27.71\%), Euryarchaeota $(60.48 \%)$ and Firmicutes $(44.24 \%)$ in the bottom, middle, and upper samples, respectively. These results revealed that the archaeal community members were dominant in almost all parts. The hydrogenotrophic methanogens in the reactor belonged to members of the Methanospirillum and Metanocella genus, but their abundance was very low. However, aceticlastic methanogens of the genus Methanosaeta were predominantly abundant in all parts of the reactor. Moreover, members of Methanosarcina were obtained in low rates (Ambuchi et al. 2016).

The number of Methanosarcinales is usually more than that of Methanomicrobiales in the methane fermentation process (Tabatabaei et al. 2010). The groups of acetotrophic, hydrogenotrophic, and methylotropic Archaea are in balance in the anaerobic system and have an equal role in the production of methane when the organic load is low. Methanosaeta sp. is predominant during the fermentation of organically rich substrates such as polysaccharides and protein rich granules in the upflow UASB (Amin \& Vriens 2014). However, environmental parameters affect the structure of the 
microbial community in the anaerobic digester. Environmental parameters are especially important for methanogenesis. Compared to bacteria, methanogens have a lower growth rate and are susceptible to environmental degradation, such as $\mathrm{pH}$ drop and high amounts of essential fatty acid and ammonia. Environmental parameters such as $\mathrm{pH}$, temperature, substrate concentration and the formation of toxic or inhibitory compounds can alter the balance in the methanogenic community structure and affect the overall treatment process. (Chen et al. 2008). Reducing the temperature to psychrophilic values can change the structure of the microbial community from acetoclastic to hydrogenotrophic methanogens. If changes in the amount and content of the substrate occur, it can affect the methanogenic community and activity. Different substrate types can cause different methanogenic communities to form (Lee et al. 2009).

\section{Conclusion}

This study revealed the detailed microbial community structure of an anaerobic digester by applying cloning, FISH and metagenomic analysis. The taxonomic analysis showed that the Euryarchaeota phylum was the most dominant in archaeal populations, while Proteobacteria, Actinobacteria, Spirochaeotes and Bacteroidetes were the

\section{References}

1. Aird, D., Ross, M. G., Chen, W. S., Danielsson, M., Fennell, T., Russ, C., Jaffe B.D., Nusbaum C. \& Gnirke, A. 2011. Analyzing and minimizing PCR amplification bias in Illumina sequencing libraries. Genome Biology, 12(2): 114. https://doi.org/10.1186/gb-2011-12-2-r18

2. Albertsen, M., Hugenholtz, P., Skarshewski, A., Nielsen, K.L., Tyson, G.W. \& Nielsen, P.H. 2013. Genome sequences of rare, uncultured bacteria obtained by differential coverage binning of multiple metagenomes. Nature Biotechnology, 31(6): 533-538. https://doi.org/10.1038/nbt.2579

3. Amann, R.I., Ludwig, W. \& Schleifer, K.H. 1995. Phylogenetic identification and in situ detection of individual microbial cells without cultivation. Microbiological Reviews, 59(1): 143-169. https://doi.org/10.1128/MMBR.59.1.143-169.1995

4. Ambuchi, J.J., Liu, J., Wang, H., Shan, L., Zhou, X., Mohammed, M.O. \& Feng, Y. 2016. Microbial community structural analysis of an expanded granular sludge bed (EGSB) reactor for beet sugar industrial wastewater (BSIW) treatment. Applied Microbiology and Biotechnology, 100(10): 4651-4661. https://doi.org/10.1007/s00253-015-7245-2

5. Amin, G.A. \& Vriens, L. 2014. Optimization of up-flow anaerobic sludge blanket reactor for treatment of composite fermentation and distillation wastewater. African Journal of Biotechnology, 13(10): 1136-1142. https://doi.org/10.5897/AJB2013.12228

6. Andersson, S. 2009. Characterization of bacterial biofilms for wastewater treatment (Doctoral dissertation, Kungliga most abundant bacterial populations in the anaerobic digestion sludge. The results showed that acetoclastic methanogenes such as Methanosaeta and Methanosarcina were predominant in the anaerobic reactor, and it was concluded that acetoclastic methanogenesis may be dominant. The anaerobic digestion system has problems due to overloading, particularly in the presence of high-strength organic wastewater such as molasses, which causes the degradation of system performance. These results will help facilitate the development of more efficient anaerobic treatment systems.

\section{Acknowledgement}

I would like to thank Prof. Dr. Mehmet Burcin MUTLU (Eskişehir-Turkey) for his scientific comments on this work.

Ethics Committee Approval: Since the article does not contain any studies with human or animal subject, its approval to the ethics committee was not required.

Conflict of Interest: The authors have no conflicts of interest to declare.

Funding: The author declared that this study has received no financial support.

Tekniska Högskolan). KTH, School of Biotechnology, Environmental Microbiology, Stockholm, Swedish.

7. Bragg, L. \& Tyson, G.W. 2014. Metagenomics using nextgeneration sequencing. In: Environmental microbiology: methods and protocols, vol. 1096. $2^{\text {nd }}$ ed, Paulsen IT., Holmes AJ, (eds.). New York City: Humana Press; 183201. https://doi.org/10.1007/978-1-62703-712-9_15

8. Caporaso, J. G., Kuczynski, J., Stombaugh, J., Bittinger, K., Bushman, F. D., Costello, E. K., \& Knight, R. 2010. QIIME allows analysis of high-throughput community sequencing data. Nature Methods, 7(5): 335-336. https://doi.org/10.1038/nmeth.f.303

9. Chen, Y., Cheng, J.J. \& Creamer, K.S. 2008. Inhibition of anaerobic digestion process: a review. Bioresource Technology, 99(10): 4044-4064. https://doi.org/10.1016/j.biortech.2007.01.057

10. Daims, H., Stoecker, K. \& Wagner, M. 2005. Fluorescence in situ hybridization for the detection of prokaryotes. In Molecular Microbial Ecology: 208-228. Osborn, A.M., Smith, C.J., (eds.) Taylor \& Francis, Abingdon, UK.

11. Gao, R., Cao, Y., Yuan, X., Zhu, W., Wang, X. \& Cui, Z. 2012. Microbial diversity in a full-scale anaerobic reactor treating high concentration organic cassava wastewater. African Journal of Biotechnology, 11(24): 6494-6500. https://doi.org/10.5897/AJB11.3142

12. Gilbride, K.A., Lee, D.Y. \& Beaudette, L.A. 2006. Molecular techniques in wastewater: understanding microbial communities, detecting pathogens, and real-time process control. Journal of Microbiological Methods, 66(1): 1-20. https://doi.org/10.1016/j.mimet.2006.02.016 
13. Guo, J., Peng, Y., Ni, B.J., Han, X., Fan, L. \& Yuan, Z. 2015. Dissecting microbial community structure and methane-producing pathways of a full-scale anaerobic reactor digesting activated sludge from wastewater treatment by metagenomic sequencing. Microbial cell factories, 14(1): 33-44. https://doi.org/10.1186/s12934$\underline{015-0218-4}$

14. Jukes, T.H. \& Cantor, C.R. 1969. Evolution of protein molecules. Mammalian protein metabolism, Munro, H.N. (ed.). New York: Academic Press. 3: 21-132. https://doi.org/10.1016/B978-1-4832-3211-9.50009-7

15. Khan, M.A., Ashar, N.N., Ganesh, A.G., Rais, N., Faheem, S.M. \& Khan, S.T. 2019. Bacterial Community Structure in Anaerobic Digesters of a Full Scale Municipal Wastewater Treatment Plant-Case Study of Dubai, United Arab Emirates. Journal of Sustainable Development of Energy, Water and Environment Systems, 7(3): 385-398. https://doi.org/10.13044/j.sdewes.d6.0222

16. Kumar, S., Stecher, G., Li, M., Knyaz, C. \& Tamura, K. 2018. MEGA X: molecular evolutionary genetics analysis across computing platforms. Molecular Biology and Evolution, 35(6): 1547-1549. https://doi.org/10.1093/molbev/msy096

17. Lane, D.J., Pace, B., Olsen, G.J., Stahl, D.A., Sogin, M.L. \& Pace, N.R. 1985. Rapid determination of 16S ribosomal RNA sequences for phylogenetic analyses. Proceedings of the National Academy of Sciences, 82(20): 6955-6959. https://doi.org/10.1073/pnas.82.20.6955

18. Lee, C., Kim, J., Hwang, K., O'Flaherty, V. \& Hwang, S. 2009. Quantitative analysis of methanogenic community dynamics in three anaerobic batch digesters treating different wastewaters. Water Research, 43(1): 157-165. https://doi.org/10.1016/j.watres.2008.09.032

19. Mutlu, M.B. \& Güven, K. 2015. Bacterial diversity in Çamalt1 saltern, Turkey. Polish Journal of Microbiology, 64(1): 37-45. https://doi.org/10.33073/pjm-2015-005

20. Nakasaki, K., Kwon, S.H. \& Takemoto, Y. 2015. An interesting correlation between methane production rates and archaea cell density during anaerobic digestion with increasing organic loading. Biomass and Bioenergy, 78: 17-24. https://doi.org/10.1016/j.biombioe.2015.04.004

21. Narihiro, T. \& Sekiguchi, Y. 2007. Microbial communities in anaerobic digestion processes for waste and wastewater treatment: a microbiological update. Current Opinion in Biotechnology, 18(3): 273-278. https://doi.org/10.1016/j.copbio.2007.04.003

22. Nayak, B.S., Levine, A.D., Cardoso, A. \& Harwood, V.J. 2009. Microbial population dynamics in laboratory-scale solid waste bioreactors in the presence or absence of biosolids. Journal of Applied Microbiology, 107(4): 13301339. https://doi.org/10.1111/j.1365-2672.2009.04319.x

23. Oksanen, J. 2013. Vegan: ecological diversity. R Project, $368 \mathrm{pp}$.

24. Raskin, L., Stromley, J.M., Rittmann, B.E. \& Stahl, D.A. 1994. Group-specific 16S rRNA hybridization probes to describe natural communities of methanogens. Applied and Environmental Microbiology, 60(4): 1232-1240. https://doi.org/10.1128/AEM.60.4.1232-1240.1994

25. Saitou, N. \& Nei, M. 1987. The neighbor-joining method: a new method for reconstructing phylogenetic trees. Molecular Biology and Evolution, 4(4): 406-425.

26. Singka, D., Kumdhitiahutsawakul, L., Rekkriangkrai, P. \& Pathom-Aree, W. 2012. A simple method for DNA extraction from activated sludge. Chiang Mai Journal of Science, 39(1): 111-118.

27. Tabatabaei, M., Rahim, R.A., Abdullah, N., Wright, A.D.G., Shirai, Y., Sakai, K., Sulaiman, A. \& Hassan, M.A. 2010. Importance of the methanogenic archaea populations in anaerobic wastewater treatments. Process Biochemistry, 45(8): 1214-1225. https://doi.org/10.1016/j.procbio.2010.05.017

28. Vaneechoutte, M., Rossau, R., De Vos, P., Gillis, M., Janssens, D., Paepe, N., De Ruck, A., Fiers, T., Claeys, G. \& Kersters, K. 1992. Rapid identification of bacteria of the Comamonadaceae with amplified ribosomal DNArestriction analysis (ARDRA). FEMS Microbiology Letters, 93(3): 227-233. https://doi.org/10.1111/j.15746968.1992.tb05102.x

29. Vanwonterghem, I., Jensen, P.D., Ho, D.P., Batstone, D.J. \& Tyson, G.W. 2014. Linking microbial community structure, interactions and function in anaerobic digesters using new molecular techniques. Current Opinion in Biotechnology, 27: 55-64. https://doi.org/10.1016/j.copbio.2013.11.004

30. Venkiteshwaran, K., Bocher, B., Maki, J. \& Zitomer, D. 2015. Relating anaerobic digestion microbial community and process function. Microbiology Insights, 8(2): 37-44. https://doi.org/10.4137/MBI.S33593

31. Ye, L., Zhang, T., Wang, T. \& Fang, Z. 2012. Microbial structures, functions, and metabolic pathways in wastewater treatment bioreactors revealed using highthroughput sequencing. Environmental Science and Technology, 46(24): 13244-13252. https://doi.org/10.1021/es303454k

32. Yıldız, S., Namal, O.Ö. \& Çekim, M. 2013. Atık su arıtma teknolojilerindeki tarihsel gelişimler. Selçuk Üniversitesi Mühendislik, Bilim ve Teknoloji Dergisi, 1(1): 55-67 (In Turkish). 